\title{
Status of Academic Librarians in Retrospect
}

A century ago few if any American academic librarians held faculty rank by virtue of their library work. Slowly some came to be recognized as responsible academic officers, usually at first without rank, and then in more recent years increasing numbers of them have been accorded full faculty status and rank. Although the struggle for improved status for academic librarians continues today, it does so "with increasing prospects for general acceptance."

$\mathrm{T}$ HE IDEA of the college and university librarian as a bona-fide member of the academic community has matured slowly, and rearguard actions against it continue to our own day. How far the profession has progressed over the past one hundred years may be judged by a brief historical review.

Examination of a cross section of the annual catalogs or registers of United States universities, private and public, for $1870-71$ reveals something of the status of librarians in leading institutions nearly a century ago:

Columbia College (later Columbia University) lists the librarian, assistant librarian, and school of mines librarian under "Officers of Instruction and Government," without academic titles. California at Berkeley included William Swinton as librarian and Professor of English, under "Faculty and Officers." Cornell University placed Professor Willard Fiske as "Librarian" under a special

Dr. Downs is Dean of Library Administration, University of Illinois. This paper is another in a series of preliminary statements prepared by the Committee on Academic Status of ACRL's University Libraries Section. Its members welcome reader comments on these papers. heading after "Faculty of the University." Dartmouth College, however, recorded the librarian's name with "Faculty," though without rank. Harvard's solution was to list the librarian and assistant librarian under "Officers of Instruction and Government." The University of Illinois used a curious title: "Librarian and Assistant Teacher." Indiana University lumped the librarian under "College Officers." At Iowa State University, the librarian doubled as Professor of Latin. The University of Michigan included the librarian and assistant librarian under the heading of "Members of Faculties and Other Officers." There was a remarkable situation at the University of Minnesota, where William W. Folwell held the combined position of president and librarian. Neither Northwestern University, nor the University of Pennsylvania, nor the University of Wisconsin was sufficiently aware of the librarian's existence to mention him in its catalog. At Princeton, the librarian was Professor of Greek, and the assistant librarian was Tutor in Greek. Yale listed the librarian, assistant librarian, and registrar at the end of the section entitled "Faculty, Instructors, and Officers."

As of 1870-71, according to this representative sample, none of the univer- 
sities gave their chief librarians academic titles, unless they were members of the teaching faculty. Apparently there was a feeling in some institutions that the head librarians ought to be grouped with the faculty, but what the relationship should be was undetermined. Consequently, the usual practice was to list them after the regular teaching staff, with their professional titles, together with registrars, museum curators, and other miscellaneous officers.

In extenuation of the institutions for their uncertainty about the place of librarians in the academic scene, it should be noted that a century ago American college libraries were in their infancy. When the American Library Association was organized in 1876, only two college libraries in the country contained more than fifty thousand volumes each, Harvard alone possessing more than one hundred thousand volumes. Library staffs were minuscule in size, in part because of the minuteness of the libraries and in part because demands on them were limited. Few faculty members held doctorates or carried on research, and students had little occasion to use the library collections.

In the famous 1876 United States Bureau of Education special report Public Libraries in the United States of America, F. B. Perkins and William Mathews ${ }^{1}$ proposed the creation of "professorships of books and reading," to guide students through the mazes of what even then was regarded as a bibliographical explosion. The instruction recommended would be primarily for the acquisition of knowledge, "the scientific use of books," i.e., sound methodology, and for "literary production." A chair of books and reading, it was suggested, might be filled by "an accomplished librarian." The first library

1 U.S. Bureau of Education, Public Libraries in the United States of America; Their History, Condition, and Management, Special Report (Washington: Government Printing Office, 1876), p. 230-51. school was still eleven years away.

By the beginning of the present century, modest advances in the status of librarians were evident. In no instance, however, among eighteen major universities checked did the librarian hold an academic title as librarian per se. The situation was as follows:

Brown University listed the librarian, assistant librarian, and four library staff members with "Officers of Administration and Instruction." California at Berkeley included the librarian in the Academic Senate, but without academic rank; the remainder of the library staff was lumped under "Assistants and Other Officers." The University of Chicago recognized the librarian by making him a member of the University Senate and University Council. At Columbia, the librarian was among "Officers of Administration"; other staff members were listed at the head of a brief sketch of the library. Cornell listed the librarian and his staff as a group under "Officers of Instruction and Administration." Harvard did the same. At Illinois, the librarian was a member of the Senate and Council and a professor, but by virtue of being director also of the library school; other librarians were listed with "Laboratory and Other Assistants." Indiana used the heading of "Library Officers" following the listing of "Faculty."

Iowa placed the librarian with "Administrative Officers" and also listed the librarian and his staff as a group under "Members of the Faculties," between lecturers and instructors. Under "Members of the Faculties and Other Officers," Michigan placed the librarian with full professors, though without rank. At Missouri, the librarian was one of "Other Officers." North Carolina included him among "Officers of Administration" and listed two other staff members under a sketch on the "University Library." Northwestern's heading of "Officers of Instruction and Government" included 
the librarian, and Pennsylvania named its librarian and assistant librarian under "Administrative Officers." Like Michigan, Princeton listed the librarian with full professors, but without an academic title; the associate librarian and reference librarian were in the list of assistant professors, again minus formal rank. A similar plan was followed by Stanford, where the librarian and associate librarian were grouped with associate professors, the assistant librarian with instructors, and other staff members with assistants. Both Texas and Wisconsin grouped the librarians and their staffs together following the listing of faculty and other officers. Finally, at Yale, the librarian and assistant librarian were under the heading of "Faculty and Instructors," again without titles; the rest of the library staff were with "Other Officers" at the end of the faculty list.

A definite trend is observable in the 1900-1901 sample in the direction of rating the head librarians as faculty, despite the fact that no breakthrough had been made toward conferring formal academic titles on them. Other than the chief librarians and one or two top associates, however, it is obvious that professional library staff members lacked any definite place in the educational hierarchy.

Voices crying in the wilderness were trying to make themselves heard at an early date. H. A. Sawtelle, writing on college librarianship, is quoted in the Library Journal, June 1878, as follows:

Time was when if a college librarian cataloged and placed his books and for half an hour twice a week charged the borrowed volumes and checked the return ones, he had sufficiently discharged his duty. But it has come to be understood that it becomes him to be daily ready to be consulted in relation to any book or subject, to converse freely with the students in regard to their reading, inspiring their literary interest, guiding their taste, bringing to their attention the right kind of appetizing works, and if needful gently leading on the reader from light and tasty books to those of high quality and permanent utility. To us nothing in the life of the college student seems to be of greater importance than just this inspiration and guidance. But all this is time consuming and requires no small amount of understanding and skill.

The writer concluded that such college librarianship as he described "ought not to be annexed to a professorship, but be itself a professorship."2

As early as 1891, President Gilman of Johns Hopkins University made the statement that: “The librarian's office should rank with that of professor.... The profession of librarian should be distinctly recognized. Men and women should be encouraged to enter it, should be trained to discharge its duties, and should be rewarded, promoted, and honored in proportion to the services they render." 3

Enlightened librarians realized that they ought to have more clearly defined status, as is revealed by stirrings in the profession early in the current century. For example, W. E. Henry, librarian of the University of Washington, speaking at the ALA conference in Pasadena in 1911, after defending the training and scholarly nature of the work of college librarians, asserted:

With such preparation and such relationship to the educational processes I shall claim that the library staff must rank with the faculty or teaching staff of any department. The librarian or head of the staff should have the rank and pay of a professor; the assistant librarian ... should be accorded the rank and pay of an associate professor; and the other members of the staff that of assistant professor or instructor, this to be determined by the nature of the work, the preparation and particular ability

\footnotetext{
${ }^{2}$ H. A. Sawtelle, "The College Librarianship," Library Journal, III (June 1878), 162.

${ }^{3}$ D. C. Gilman, "University Libraries, an Address at the Opening of the Sage Library of Cornell University, October 7, 1891," University Problems in the United States, 1898, p. 245-55.
} 
required; and those not fitted to so rank should not be members of the staff but some other name should be adopted.4

Mr. Henry's goal had not been achieved at the University of Washington at the time of his address. The librarian and five members of his staff were grouped under "Library Staff," without academic titles, near the end of the section on "Faculty and Officers." According to returns from questionnaires sent by Henry to sixteen college and university libraries across the country, however, he reported, "it appears that the librarian usually has the rank of a professor [sans title?] Below the librarian all sorts of conditions prevail."5

An important step forward was taken in the same year, 1911, by the Columbia University trustees, who ruled: "The librarian shall have the rank of professor, the assistant librarian that of associate professor and the supervisors shall rank as assistant professors and bibliographers as instructors." From Harvard University it was reported that "librarians and assistant librarians" were eligible to participate in the faculty retirement system.

A few years later, E. C. Richardson, noted librarian of Princeton University, reviewed the place of the library in a university and concluded that its position would be determined by the effectiveness with which its teaching function was discharged. Richardson pointed out that the growth of research work, the advent of the research professor, and the establishment of library schools had brought librarians "into the circle of the teaching faculties." 6 Authoritative support for this contention came from President Nicholas Murray Butler of Columbia, who held that the library was coordinate with the various professional

\footnotetext{
${ }^{4}$ W. E. Henry, "The Academic Standing of College Library Assistants and Their Relation to the Carnegie Foundation," Bulletin of the American Library Association, V (May 1911), 259-60.

${ }^{5}$ Ibid., 262

'E. C. Richardson, "The Place of the Library in a University," Ibid., X (January 1916), 1-13.
}

schools and main departments of the university, the librarian ranking as a dean, and various members of the professional staff standing in parallel order with professors, assistant professors, and instructors of the other faculties. ${ }^{7}$

About the same time a strong statement from W. N. C. Carlton, librarian, Newberry Library, objected to the fact that in some institutions "the librarian is not granted a seat and vote in the faculty. This," the writer went on, "is a viciously bad practice. Its evils are too patent to need illustration. If a man is not qualified for the duty and responsibility of sharing in the debates, consideration, and decisions relating to general university policy and administration, he ought not to be appointed librarian, whatever his technical qualifications may be."

A subordinate staff member was heard from nearly fifty years ago when J. T. Jennings, then reference librarian of Iowa State College, wrote about "Librarianship as a Profession in College and University Libraries." Jennings was convinced that the chief librarian's position in most college and university communities had become well established "in dignity, in importance, in salary," ranking as the head of one of the most important departments. "But what about the remainder of the library staff?" he asked. "With the exception of a possible assistant librarian they are usually considered 'mere clerks,' as is shown by their salaries, their hours of work, and the attitude of their superiors toward granting them opportunities for advancement." Jennings was inclined to blame this state of affairs on the head librarians who were not sufficiently energetic in encouraging and assisting junior staff members to improve their educational and professional prepara-

\footnotetext{
? Ibid., V (1911), 13.

8 W. N. C. Carlton, "Universities and Librarians," Public Libraries, XX (December 1915), 455.
} 
tion, as junior members of the teaching faculty were expected to do. ${ }^{9}$

The same conclusion was reached by another reference librarian, Edith $\mathrm{M}$. Coulter, of the University of California, writing in 1917. Even the chief librarians, she pointed out, lacked certain privileges customarily belonging to the teaching faculty, such as extended vacations, leaves of absence, and sabbaticals for advanced study and research. Proper recognition would come to librarians, Miss Coulter held, if they participated more actively in teaching e.g., bibliographic instruction to university students; if the programs of library schools were standardized, more doctoral degrees were held by librarians, requirements for appointments to university library staffs were raised, professional and clerical duties were differentiated, and more study and research were done by librarians. Miss Coulter displayed remarkable foresight in urging a doctoral program in library science more than a decade before the establishment of the graduate library school in Chicago. ${ }^{10}$

The first full exploration of the status of professional librarians was undertaken by George A. Works, in his College and University Library Problems, based on data collected in 1925. In a chapter devoted to the subject, Dr. Works reviewed types of library work, factors affecting the status of a library staff, current conditions, the relative preparation of library and teaching staffs, comparative salaries, work schedules, and retirement provisions. Among the important conclusions were these: (1) insufficient distinction is made in libraries between clerical and professional types of service, but there are a number of positions in every large library whose requirements in professional education

${ }^{9} \mathrm{~J}$. T. Jennings, "Librarianship as a Profession in College and University Libraries," Library Journal, XLIII (April 1918), 227-33.

${ }^{10}$ Edith M. Coulter, "The University Librarian: His Preparation, Position and Relation to the Academic Department of the University," Bulletin of the American Library Association, XVI (July 1922), 271-75. and experience are comparable with the requirements for positions in the various grades in the teaching staff; (2) among the seventeen institutions studied, wide differences were found, varying from those in which librarians held faculty rank to others in which the library staff, except the librarian and perhaps one or two others, were classified as clerical; (3) in some universities, e.g., Columbia and Stanford, librarians were given equivalent status, but not considered members of the instructional staff; (4) except for the head librarian, salaries of the library staff were generally lower than those of comparable members of the faculty; (5) the academic preparation of faculty members of all professional ranks was more advanced than that of library department heads; (6) no account was taken of the fact that annual periods of service were ordinarily longer for members of the library staff than for the teaching staff; (7) retirement provisions varied: seven institutions had no allowance for faculty or librarians; six had the same retirement arrangements for both groups, and three had different arrangements for faculty and librarians. ${ }^{11}$

A decade later an outstanding university president, Henry M. Wriston, whose ideas have had considerable impact on academic library service, set forth his concept of the proper relationships between the college librarian and the teaching staff. "The librarian," concluded Dr. Wriston, "despite his administrative duties is primarily an officer of instruction. He should have the scholarly interests and tastes which are expected of other members of the faculty. He should be given faculty status and should participate in all the committee and other discussions incidental to that status." In harmony with this proposal, the writer added that the li-

\footnotetext{
11 George A. Works, "The Status of the Professional Staff." In his College and University Library Problems (Chicago: ALA, 1927), p. 80-98.
} 
brary "should be treated not as an ancillary enterprise but as one of the central sources of motive power for the operation of the institution."12

During the past thirty years, the literature relating to the status of college and university librarians has proliferated, including the findings of a number of comprehensive surveys. The first, after Works, was Miriam C. Maloy's study, published in 1939. Among the 129 institutions investigated, Mrs. Maloy found that ninety-eight chief librarians had faculty status, and thirty-one did not; among assistant and associate librarians, thirty had faculty status and forty did not; department heads had faculty status in twenty-seven libraries and no academic rank in four; and professional assistants were granted faculty status in twenty libraries, but not in thirty others. In each of the four categories, the status frequently was nominal. ${ }^{13}$

Following shortly after the Maloy study were a number of other general or limited investigations: James A. McMillen examined the status of library staff members of large universities (1940);14 Robert W. McEwen, the status of college librarians (1941); $;^{15}$ Rice Estes; faculty status in the City College Libraries (1941); ${ }^{16}$ general surveys were reported by Leonard $H$. Kirkpatrick (1947), ${ }^{17}$ Morris A. Gelfand (1948), ${ }^{18}$ Humphrey G. Bousfield (1948), ${ }^{19}$ and by Frank A. Lundy $(1951)^{20}$ and Law-

12 Henry M. Wriston, "The College Librarian and the Teaching Staff," Bulletin of the American Library Association, XXIX' (April 1935), 182.

${ }^{13}$ Miriam C. Maloy, "Faculty Status of College Librarians," ALA Bulletin, XXXIII (April 1939), 232$33,302$.

14 James A. McMillen, "Academic Status of Library Staff Members of Large Universities," CRL, I (March 1940), 138-40.

15 Robert W. McEwen, "The Status of College Librarians," Ibid., III (June 1942), 256-61.

${ }_{10}$ Rice Estes, "Faculty Status in the City College

Libraries," Ibid., Ill (December 1941), 43-45.

${ }^{17}$ Leonard H. Kirkpatrick, "Another Approach to Staff Status," Ibid., VIII (July 1947), 218-20.

18 Morris A. Gelfand, "The College Librarian in the Academic Community," Ibid., X (April 1949), 129-34, 139.

18 Humphrey G. Bousfield, "College Libraries with Dual Roles," Ibid., IX (January 1948), 25-32.

${ }^{20}$ Frank A. Lundy, "Faculty Rank for Professional Librarians," Ibid., XII (January 1951), 11-19, 109-22. rence S. Thompson $(1952)^{21}$ as well as by Robert B. Downs (1954 and 1957);22 and Robert $H$. Muller reviewed the question of faculty rank for library staff members in medium-sized universities and colleges (1953)..$^{23}$ Evidence of lively continued interest is shown by more recent articles published by Carlson, ${ }^{24}$ Knapp, ${ }^{25}$ Branscomb, ${ }^{26}$ McAnally, ${ }^{27}$ Veit, ${ }^{28}$ and others.

Progress achieved by university librarians since the first feeble beginnings a century ago may be estimated further from a summary of conditions prevailing in $1964 .^{29}$ Academic status for librarians, it was then reported, had become firmly established in a considerable number of American universities. New converts, principally among state institutions, had swelled the ranks of those universities where librarians are accorded the responsibilities and perquisites of academic or faculty status. Considerable diversity was discovered, however, among the forms of recognition received. In certain instances, agreement upon the principle of academic standing for librarians was limited or qualified. The struggle by academic librarians for improved standing obviously continues, but with increasing prospects for general acceptance.

${ }^{21}$ Lawrence S. Thompson, "Preparation and Status of Personnel," Library Trends, I (July 1952), 95-104.

${ }_{22}$ Robert B. Downs, "Are College and University Librarians Academic?" CRL, XV (January 1954), 9-14; and "The Current Status of University Library Staffs," Ibid., XVIII (September 1957), 375-85.

${ }^{23}$ Robert H. Muller, "Faculty Rank for Library Staff Members in Medium-Sized Universities and Colleges," Bulletin of the American Association of University Professors, XXXIX (Autumn 1953), 421-31.

${ }^{24}$ William H. Carlson, "The Trend Toward Academic Recognition of College Librarians," CRL, XVI (January 1955), 24-29.

${ }^{25}$ Patricia B. Knapp, "The College Librarian; Sociology of a Professional Specialization," Ibid., XVI (January 1955), 66-72.

${ }^{26}$ Lewis C. Branscomb, "The Quest for Faculty Rank." In: R. B. Downs, ed. The Status of American College and University Librarians (Chicago: ALA, 1958), p. 42-46.

${ }^{27}$ Arthur M. McAnally, "The Dynamics of Securing Academic Status," CRL, XVIII (September 1957), 386-95; and "Privileges and Obligations of Academic Status," Ibid., XXIV (March 1963), 102-08.

${ }^{28}$ Fritz Veit, "The Status of the Librarian According to Accrediting Standards of Regional and Professional Associations," Ibid., XXI (March 1960), 127-35.

${ }_{29}$ Robert B. Downs, "Status of University Librarians -1964," Ibid., XXV (July 1964), 253-58. 